\title{
Domestic, peridomestic and wild hosts in the transmission of Trypanosoma cruzi in the Caatinga area colonised by Triatoma brasiliensis
}

\author{
Claudia Mendonça Bezerra ${ }^{1,2}$, Luciano Pamplona de Góes Cavalcanti ${ }^{3,4}$, \\ Rita de Cássia Moreira de Souza ${ }^{5}$, Silvia Ermelinda Barbosa ${ }^{5}$, Samanta Cristina das Chagas Xavier ${ }^{6}$, \\ Ana Maria Jansen ${ }^{6}$, Relrison Dias Ramalho ${ }^{2}$, Liléia Diotaiuti ${ }^{5 /+}$

\begin{abstract}
1Programa de Pós-Graduação em Saúde Comunitária ${ }^{3}$ Departamento de Saúde Comunitária, Universidade Federal do Ceará, Fortaleza, CE, Brasil ${ }^{2}$ Secretaria de Saúde do Estado do Ceará, Fortaleza, CE, Brasil ${ }^{4}$ Centro Universitário Christus, Fortaleza, CE, Brasil ${ }^{5}$ Centro de Pesquisa René Rachou-Fiocruz, Belo Horizonte, MG, Brasil ${ }^{6}$ Laboratório de Biologia de Tripanosomatídeos, Instituto Oswaldo Cruz-Fiocruz, Rio de Janeiro, RJ, Brasil
\end{abstract}

The role played by different mammal species in the maintenance of Trypanosoma cruzi is not constant and varies in time and place. This study aimed to characterise the importance of domestic, wild and peridomestic hosts in the transmission of T. cruzi in Tauá, state of Ceará, Caatinga area, Brazil, with an emphasis on those environments colonised by Triatoma brasiliensis. Direct parasitological examinations were performed on insects and mammals, serologic tests were performed on household and outdoor mammals and multiplex polymerase chain reaction was used on wild mammals. Cytochrome $b$ was used as a food source for wild insects. The serum prevalence in dogs was $38 \%$ (20/53), while in pigs it was $6 \%$ (2/34). The percentages of the most abundantly infected wild animals were as follows: Thrichomys laurentius $74 \%$ (83/112) and Kerodon rupestris 10\% (11/112). Of the 749 triatomines collected in the household research, 49.3\% (369/749) were positive for $\mathrm{T}$. brasiliensis, while $6.8 \%$ were infected with $\mathrm{T}$. cruzi (25/369). In captured animals, T. brasiliensis shares a natural environment with T. laurentius, K. rupestris, Didelphis albiventris, Monodelphis domestica, Galea spixii, Wiedomys pyrrhorhinos, Conepatus semistriatus and Mus musculus. In animals identified via their food source, T. brasiliensis shares a natural environment with G. spixii, K. rupestris, Capra hircus, Gallus gallus, Tropidurus oreadicus and Tupinambis merianae. The high prevalence of $\mathrm{T}$. cruzi in household and peridomiciliar animals reinforces the narrow relationship between the enzootic cycle and humans in environments with $\mathrm{T}$. brasiliensis and characterises it as ubiquitous.

Key words: Triatominae - Triatoma brasiliensis - Trypanosoma cruzi - hosts - semiarid

Trypanosoma cruzi Chagas, 1909 (Trypanosomatida: Trypanosomatidae) (Moreira et al. 2002), the etiologic agent of Chagas disease, is a obligate protozoan parasite that is capable of infecting dozens of species of triatomine vectors (Hemiptera: Reduviidae: Triatominae) (Silveira \& Rezende 1994, OPAS 2006) and hundreds of species of mammals belonging to over 70 types (Noireau et al. 2009, Zingales et al. 2012).

Infection is characterised by a series of very complex elements, which include bio-ecological determinants (relationship between vectors, parasites and reservoirs), cultural factors (types of homes and way of life) and socioeconomic factors (occupation of territories and labour relations). Human infection is the result of direct action of man over nature, occurring when people invade the enzootic cycle of T. cruzi (Dias 2000, Noireau et al. 2009).

doi: 10.1590/0074-0276140048

Financial support: WHO/TDR (A70596),

CNPq, CPqRR/FIOCRUZ-MG, SES-CE

+ Corresponding author: diotaiut@cpqrr.fiocruz.br

Received 7 February 2014

Accepted 2 July 2014
The different strategies of parasite transmission between mammals and vectors with different biological and ecological characteristics have resulted in the maintenance of parasites in distinct cycles. This restriction, in turn, has resulted in the evolutionary transformation from foci of enzootic transmission in restricted habitats to complex networks interconnected by domestic and wild species with a wide geographical distribution (Araújo et al. 2009).

The roles of the different species of mammals in the maintenance of the parasite are not constant according to time or region (Ashford 1996, 1997). Despite the long list of mammalian species that are naturally infected by T. cruzi, the role that each reservoir species plays in the dispersal and/or maintenance of the parasite can be extremely variable in distinct transmission cycles of $T$. cru$z i$ in nature. This variation is mainly due to the complexity of these processes, ecological inter-relationships and the high speed with which man modifies environments (Noireau et al. 2005, Ceballos et al. 2006, Jansen 2009).

The Brazilian Northeast Region plays an important role in the national context of the epidemiology of Chagas disease (Dias 2000). The Caatinga region is ranked third in triatomine diversity, containing $15(24 \%)$ of the described species (Gurgel-Gonçalves et al. 2012). Triatoma brasiliensis Neiva, 1911, is the species of triatomine of greatest importance in the domestic transmission of Cha- 
gas disease in the region, thus its control is a priority (Silveira et al. 1984, Dias et al. 2000). Despite the fact that the household population can be controlled through the use of insecticides with residual action, homes are recolonised at high speeds, requiring permanent vigilance against new outbreaks (Diotaiuti et al. 2000, Borges et al. 2005).

It is known that the adaptation of triatomines to artificial ecotopes is what determines their condition as vectors of epidemiological importance of $T$. cruzi. This ability depends primarily on two features: the ability to feed on the sources of blood available in the house and the ability to survive the microclimatic factors (temperature and humidity) determined by household hideouts (Lent \& Wigodzinsky 1979, Lorenzo et al. 2000). In addition, man-made environmental changes favour the dispersion of triatomines (Forattini 1980) and the attraction of insects to household by light sources (Carbajalde-la-Fuente et al. 2007). For T. brasiliensis, it has been shown that the adaptation of these insects to the intradomicile lifestyle is favoured by microclimatic similarities between households and natural ecotypes of the species in the state of Ceará (CE) (Lorenzo et al. 2000).

This work aims to characterise the importance of domestic, wild and peridomestic hosts in the transmission of $T$. cruzi in a rural area of CE, with an emphasis on environments colonised by T. brasiliensis.

\section{MATERIALS AND METHODS}

Research area - The study was conducted in the municipality of Tauá (CE) (Fig. 1), a region that has historically presented a near totality of homes infested by triatomines, with $T$. brasiliensis being the main vector species. Eighteen sites distributed throughout the district of Carrapateiras and totalling 252 households (UDs) were selected. In this case, the term "UD" refers to the peridomestic and domestic environments, that is, human habitations and their surroundings, with all permanent and temporary buildings, accumulations of materials, fences, animal shelters etc.

Tauá is located in the hinterland of Inhamuns $\left(6^{\circ} 00^{\prime} 11^{\prime \prime} \mathrm{N} 40^{\circ} 17^{\prime} 34^{\prime \prime} \mathrm{S}\right)$ at an altitude of $402.7 \mathrm{~m}, 320 \mathrm{~km}$ from the capital, Fortaleza. The average temperature varies between $26-28^{\circ} \mathrm{C}$, with an average rainfall of $597.2 \mathrm{~mm}^{3}$, with a rainy season from February-April (IPECE 2012). In this region, the vegetation of the savannah is highly degraded, with physiognomic patterns marked by the secondary succession of predominant shrub and tree savannah. The predominant vegetation is deciduous and garranchenta, growing in shallow and stony soils, with an extreme water deficit for much of the year (Oliveira 2006). The economic activities are restricted to agricultural and extensive cattle activities, with very low incomes and negligible productivity (Oliveira 2006). In this context, crystalline basement rocks, mainly granitic rocks with significant fractures, provide habitats for small mammals, reptiles and insects. Amongst them is T. brasiliensis, for which this environment is its natural habitat (Forattini 1980).

Mammal capture - Wild - Rock formations that could be natural shelters for $T$. brasiliensis are identified with the presence of small wild animals such as rodents and marsupials, a fact confirmed by an active search for

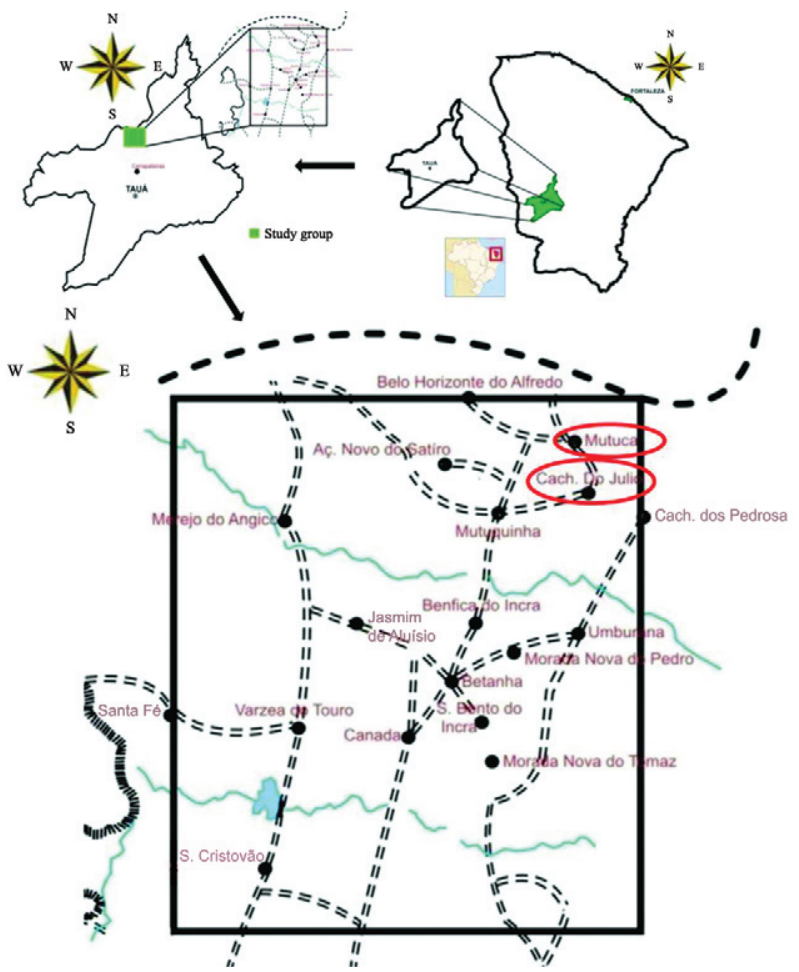

Fig. 1: geographical location of the study sites (Mutuca and Cachoeira do Júlio, highlighted in red), municipality of Tauá, state of Ceará. Source: alunosonline.com.br/geografia/ceara.html (accessed in 4 June 2009) and archives of the Chagas Disease Control Program of Health Department of the State of Ceará.

traces of these insects and mammals. Three areas were selected: two in Mutuca, that were $2.6 \mathrm{~km}$ apart each other and identified as: Pedra da Cruz (MPC) (adjacent to residences - $94 \mathrm{~m}$ and more susceptible to human intervention) and Seu Evangelista (ME) (with intermediate distance to the residences - $211 \mathrm{~m}$ and less susceptible to human intervention) and Cachoeira do Júlio (CJ) (distant residences $-370 \mathrm{~m}$ and virtually no human intervention at $5.4 \mathrm{~km}$ away from MPC). In these places, the traps were placed in transects. The traps were latticework traps with trigger hooks in small $(33 \times 14 \times 10 \mathrm{~cm}-250$ units), medium ( $33 \times 12 \times 14 \mathrm{~cm}-46$ units), large ( 46 x $16 \times 19 \mathrm{~cm}-11$ units) and large tomahawk (50 x 21, 5 x $20 \mathrm{~cm}-9$ units) sizes, suitable for catching animals of different sizes and weights. The traps remained in the field for 16 days and were deployed in four distinct campaigns (February/2009, August/2009, February/2010 and August/2010) of four days and nights each. The periods chosen reflect the maximum drought period (February) and the immediate following period (August), in which we would expect to observe the behaviour and population structure of different animals.

The bait used was a mixture of bacon, oatmeal, bananas, peanut butter and corn on the cob (D'Andrea et al. 2006). The traps were baited in the evening and were revisited at dawn. Lactating or cub-bearing marsupials were not sampled. These and other non-rodents were returned to the wild at the capture site after the experimental procedure. 
For convenience, sampling was defined by the total trap catch per day of effort during the period of exposure (sum of traps by type multiplied by the exposure period) (Torres et al. 2008). The ultimate goal was to search for a general representation of fauna infected with $T$. cruzi, whether the animals were recaptured or not.

The captured animals were anesthetised with a combination of ketamine and xylazine intramuscularly with 1 $\mathrm{mL}$ syringes. The following data were collected: species type, location of capture, sex and age (adult/juvenile). In addition, blood samples were collected by puncturing the tail vein and collecting a maximum of $1 \mathrm{~mL}$ of blood from rodents and $3 \mathrm{~mL}$ from marsupials, considering the weight of each animal.

Domestic and peridomestic - The domestic and peridomestic sample was defined as including all dogs, cats and pigs encountered during the visits to residential localities of Mutuca and CJ. For ovine and caprine specimens, the herd records available in the Agency of Agricultural Defense of Ceará State were used to define sampling based on finite and known prevalence populations, separated by animal species, sex and age (individuals less than 6 months of age were classified as young and those older than 6 months as adult). For this study, only animals under six months of age were used in attempts to identify recent caprine contact with $T$. cruzi.

In the domestic and peridomestic environments, the collection of blood from dogs and cats was performed by femoral vein puncture, while for pigs, sheep and goats it was performed by the jugular vein puncture. The same data were collected as described above for wild animals, including the environment frequented by the animals (wild, peridomestic and indoor) and how long they had lived in that house or its surroundings. All procedures were performed under the guidance of responsible professionals and followed the general recommendations as to the integrity and well-being of the animals and signed consent forms were obtained from the owners or guardians.

Diagnosis of infection with T. cruzi - Parasitological - Two sheets of thick films were prepared by using mammalian specimens and stained with Giemsa stains. One hundred fields per drop were observed by optical microscopy with a magnification of $1,000 X$ (FIOCRUZ 2008).

Serological - Three methods of serological diagnosis were used: immunofluorescence assay (IFA), according to Camargo (1966), immunoenzymatic assay (ELISA indirect) and immunochromatographic rapid test and dual path platform test (RT-DPP).

The reactions were developed with $\operatorname{IgG}$ conjugated to fluorescein isothiocyanate (Sigma). For differential diagnosis, all sera were tested for infection with Leishmania spp by the IFA method and for Leishmania infantum using the quick test for diagnosis of canine visceral leishmaniasis (CVL) (DPP) specific Bio-Manguinhos for dogs (MS/SVS 2006, 2011).

In the IFA, the cut-off values for serum titres in domestic mammals were $\geq 1: 40$ for dogs and cats and $>1: 40$ for the other species. The results were expressed as the highest serum dilution at which specific fluorescence is still observed. The reaction reading was taken using a fluores- cence compound microscope with a high intensity light source (ultraviolet light). The cut-off for the ELISA was established by taking the average of the optical density of the negative control and adding $20 \%$ to that value. The quantification of the reaction was determined by spectrophotometer readings at a wavelength of $450 \mathrm{~nm}$. The data were only considered suspicious or ambiguous in one method and in reactions with dilution cut-offs. With the Rapid Test on DPP ${ }^{\circledR}$ LVC, we followed the manufacturers' instruction accompanying the CVL-Bio-Manguinhos RT KIT DPP ${ }^{\circledR}$. All reactions included two positive controls and two negative controls. The prevalence of infection was calculated by obtaining the percentage of individuals who exhibited positive results in both serological tests.

Molecular - Polymerase chain reaction (PCR) multiplex - Whole blood samples were placed on filter paper (Whatman $\mathrm{N}^{\circ}$ 1), dried, wrapped in aluminium foil and isofilm and stored individually at $-20^{\circ} \mathrm{C}$. Samples were subjected to multiplex PCR for the diagnosis and characterisation of T. cruzi in TcI or TCII.

DNA was extracted from the samples on filter paper was extracted from $1 \mathrm{~mm}$ punched samples in individual microtubes. In each tube, we added $100 \mu \mathrm{L}$ of deionised water and the sample was heated at $70^{\circ} \mathrm{C}$ for $10 \mathrm{~min}$ and centrifuged for $3 \mathrm{~min}$ at 17,900 $\mathrm{g}$ (Machado et al. 2000). The supernatant containing the DNA was stored at $4^{\circ} \mathrm{C}$ and used for PCR.

As a positive control, we used the default Colombian and $\mathrm{Y}$ strains belonging to groups TcI and TCII, respectively. After PCR, $3 \mu \mathrm{L}$ of the product was visualised on $6 \%$ polyacrylamide gel and stained with $0.2 \%$ silver nitrate to reveal the presence of specific bands.

Characterisation of the infestation and natural infection with T. cruzi - All households in the selected locations were manually searched by agents for endemic infestation in a thorough manner using the Manual of Technical Standards Campaign for the Control of Chagas Disease of the Ministry of Health (MS/SUCAM 1980). All surfaces, internal and external walls, furniture, utensils and other miscellaneous objects (MS/SUCAM 1980) were observed. In addition to this routine information, we noted the specific capture location of any triatomines. The intradomicile location was considered to be a single location, while the peridomicile location was divided into multiple types of attachments: chicken coops, sties, barns, firewood, stones, tiles and bricks and other.

Indices of infestation ( $\%$ of positive UD's for triatomines in relation to surveyed) of natural infection (\% of triatomines infected with $T$. cruzi in relation to those examined) and of colonisation (\% of positive houses with nymphs inside the home in relation to defined number of positive houses in households) were calculated.

The field research for the wild environments of triatomines was performed manually at dusk, with the aid of lanterns, in the same places where mammals were captured in the February/2009 and August/2009 campaigns for four consecutive nights. The insects were separated by location for later identification of species, developmental stage, T. cruzi infection status and identification of dietary sources. 
Identification of dietary source - Cytochrome $b$ (Cytb) - The identification of the food source was performed specifically to complement the list of wild animals that share the environment with $T$. brasiliensis.

Total DNA was extracted from the abdomen of insects (previously preserved in 70\% alcohol) using the HotShot protocol (Truett et al. 2000). We used the primers L14841 5'-AAAAAGCTTCCATCCAACATCTCAGCATGATGAAA-3' and H151495'-AAACTGCAGCCCCTCAGAATGATATTTGTCCTCA 3'; these universal primers are designed for vertebrates (Kocher et al. 1989). They amplify a $305 \mathrm{bp}$ fragment and do not amplify any triatomine DNA present in the animal tissue.

The PCR was performed in a final volume of $25 \mu \mathrm{L}$, containing 40-50 ng of genomic DNA, $2.5 \mu \mathrm{L}$ of $10 \mathrm{X}$ buffer, $2.0 \mu \mathrm{L}$ of $2.5 \mathrm{mM}$ dNTP, $0.75 \mu \mathrm{L}$ of $50 \mathrm{mM} \mathrm{Mg}$ $\mathrm{Cl} 2,2.5 \mathrm{~mL}$ of each primer at a final concentration of $10 \mathrm{pmol}$ and $0.2 \mu \mathrm{L}$ of Taq polymerase $0.5 \mathrm{U} / \mu \mathrm{L}$ (Invitrogen). For each PCR reaction, a negative control (no DNA) was run in parallel.

The amplifications were performed using a thermal cycler (Eppendorf Mastercycler) with the following conditions for the reaction sequences: initial denaturation $95^{\circ} \mathrm{C}$ for $5 \mathrm{~min}, 95^{\circ} \mathrm{C}$ for $30 \mathrm{~s}$, primer annealing at $58^{\circ} \mathrm{C}$ for $30 \mathrm{~s}$, extension at $72^{\circ} \mathrm{C}$ for $1 \mathrm{~min}$, return to step 2 and repeat 35 times and a final extension at $72^{\circ} \mathrm{C}$ for $6 \mathrm{~min}$. The amplified products were observed in $8 \%$ polyacrylamide gel stained with $0.2 \%$ silver nitrate.

For samples found to be positive by PCR, the products were purified using the QIAquick PCR Purification Kit (Qiagen) according to the manufacturer's protocol. After purification, the quality and concentration of DNA were measured by spectrophotometry using the Nanodrop ND 1000 and the sample purity was determined by their 260/280 $\mathrm{nm}$ absorbance ratio, followed by sequencing (ABI 3730xl DNA; Applied Biosystems).

To identify the host species associated with triatomine, the sequences obtained were compared with sequences deposited in GenBank using the BLASTN search.

Ethics - The project was submitted to the Animal Ethical Committee of the Federal University of Ceará (protocol 103, October 2011) and approved by the Chico Mendes Institute for Biodiversity Conservation of the Ministry of Environment through the Biodiversity Authorization and Information System (SISBIO) (case 31693-1, authentication code 46619742).

\section{RESULTS}

Parasitological diagnosis - The parasitological diagnosis by thick smear was negative for all 317 domestic and peridomestic animals tested (106 ovine, 83 caprine, 53 dogs, 41 cats and 34 porcine) as well as for all 112 wild animals tested (83 Thrichomys laurentius, 11 Kerodon rupestris, 5 Rattus rattus, 4 Didelphis albiventris, 3 Monodelphis domestica, 2 Galea spixii, 2 Wiedomys pyrrhorhinos, 1 Conepatus semistriatus and 1 Mus musculus).

Serological and molecular diagnosis of infection with T. cruzi - Serology of domestic mammals - In the $53 \mathrm{dog}$ samples investigated for infection with T. cruzi, $74 \%$ $(39 / 53)$ and $85 \%$ (45/53) were seropositive in ELISA and
IFA techniques, respectively (Tables I, II). For the 41 samples from cats, tests for anti-IgG T. cruzi showed that $51 \%(21 / 41)$ had an IFA result of $\geq 1: 40$. Table I shows the diagnoses of T. cruzi, Leishmania spp and L. infantum determined by different techniques: IFA, ELISA, RT-DPP LVC and PCR multiplex in domestic mammals, according to age group. Among the dogs positive for $T$. cruzi, ages ranged from eight months to 15 years, with an average of three years.

Serology of peridomestic mammals - The diagnosis of natural infection by T. cruzi in sheep, goats and pigs, as determined by multiplex PCR and IFA. The positive sheep come from CJ and most suspect animals [59.4\% (19/32)] are from Mutuca. Among the caprine suspects, $64 \%$ (7/11) were from CJ. Pigs positive for T. cruzi were a female of 10 months from CJ and a year-old male from Mutuca.

Wild mammals - The success of the total catch was $9.6 \%$, with an overall effort of 1,165 trap-nights in four stages and three locations. The numbers of species collected in MPC, $\mathrm{ME}$ and $\mathrm{CJ}$ were five, five and four, respectively. Among rodents and marsupials, a total of nine species were captured, corresponding to 112 samples (Table III).

In 2009, the predominant capture of adult males [ $44 \%$ $(32 / 73)]$ and young males [30\% (22/73)] was observed, but the presence of young and adult females was also observed, with a success catch by site and study period of $23.6 \%$ (73/309), representing $65 \%$ of all animals sampled. In $2010,79.5 \%$ (31/39) of animals captured were young males, with successful capture rate of $4.6 \%$ (39/853), even with an effort that was 2.7 times greater than in 2009 .

By correlating rainfall and capture effort within our wild animal capture data, we found that at the end of the drought period (February 2009/March 2010), the number of animals taken was $10 \%$ less than the number of animals captured in the early dry season (August 2009/2010), with a predominance of young male animals $(45 \%$ - 23/51), followed by adult males $(33 \%-16 / 51)$. At the beginning of the dry season (August 2009/2010), the capture of young male animals was higher, corresponding to $49 \%(30 / 61)$.

Table III shows that there was no difference between the number of species caught in the wild, the period of rainfall incidence and the abundance of the two main species found.

PCR multiplex - The 124 samples (43 dogs, 11 goats, 23 cats, 36 ovine and 11 porcine) considered to be positive or doubtful for T. cruzi by serological diagnosis were subjected to molecular characterisation using multiplex PCR, including 11/115 (8.8\%) amplified fragments to characterise the presence of DNA from TCI (all dogs) (Table II). For the 24 samples (22 T. laurentius and $2 R$. rattus) captured in February/2009, no amplified fragments were characterised by the presence of DNA from T. cruzi.

Domiciliary triatomine infestation and infection by T. cruzi - Two hundred fifty-one UDs were surveyed in February and March of 2009 and in the 18 sites of the study, 39\% (97/251) were positive, $12.3 \%$ (31/97) of which were in households, 29\% (73/97) in peridomicile areas and $7.2 \%(7 / 97)$ in both environments. All locations investigated exhibited the presence of insects, with an average infestation rate of $40 \%$, ranging from $16-100 \%$. 


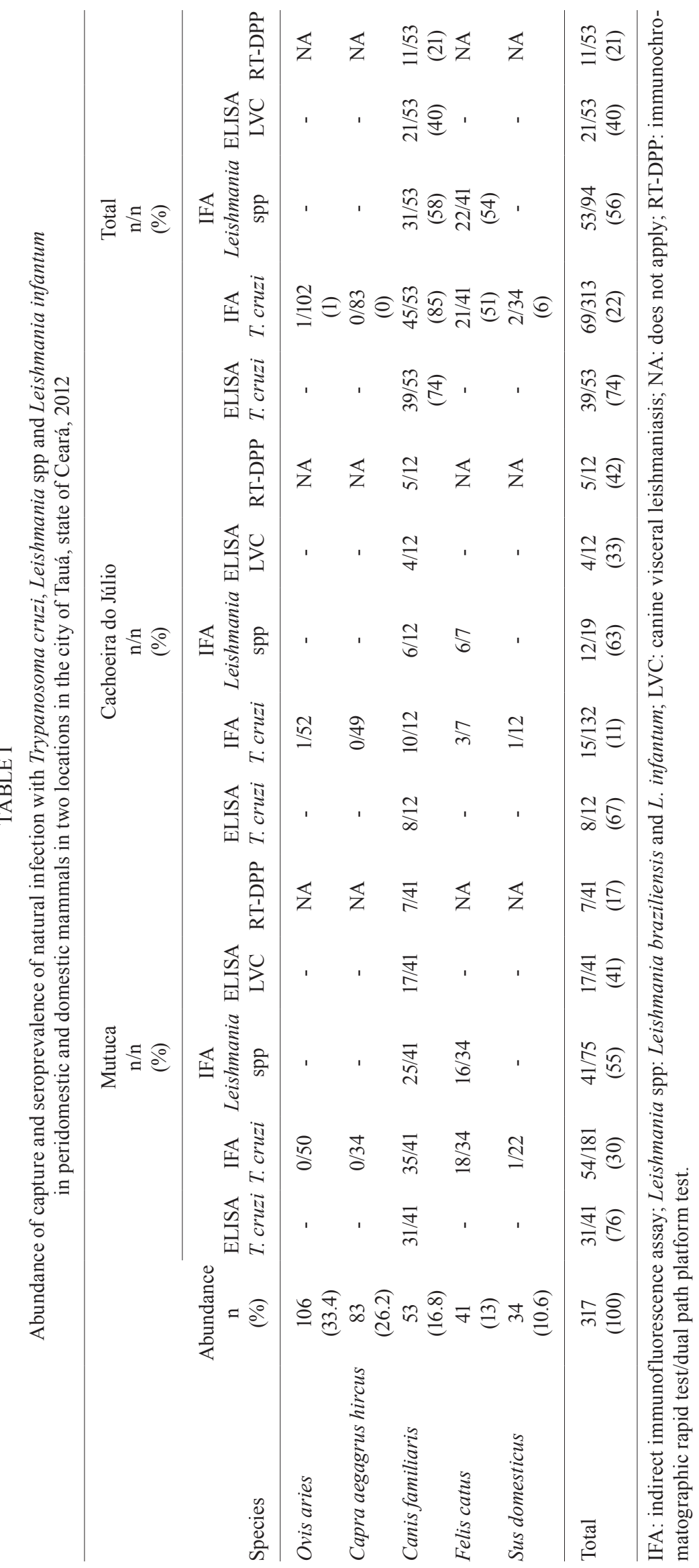




\section{TABLE II}

Diagnosis of Trypanosoma cruzi, Leishmania spp and Leishmania infantum determined by techniques of indirect immunofluorescence assay, ELISA, immunochromatographic rapid test/dual path platform test-canine visceral leishmaniasis and polymerase chain reaction PCR multiplex in domestic mammals, according to age group in the city of Tauá, state of Ceará, 2012

\begin{tabular}{|c|c|c|c|c|c|c|c|c|}
\hline Species & $\begin{array}{l}\text { Age } \\
\text { group } \\
\text { (years) }\end{array}$ & $\begin{array}{l}\text { T. cruzi } \\
\mathrm{n} / \mathrm{n}(\%)\end{array}$ & $\begin{array}{l}\text { Leishmania spp } \\
\mathrm{n} / \mathrm{n}(\%)\end{array}$ & $\begin{array}{l}\text { L. infantum } \\
\text { n/n }(\%)\end{array}$ & $\begin{array}{c}\text { T. cruzi and } \\
\text { Leishmania } \mathrm{spp} \\
\mathrm{n} / \mathrm{n}(\%)\end{array}$ & $\begin{array}{l}\text { T. cruzi and } \\
\text { L. infantum } \\
\text { n/n }(\%)\end{array}$ & $\begin{array}{c}\text { T. cruzi } \\
\text { (title = } 1: 40) \\
\text { n/n }(\%)\end{array}$ & $\begin{array}{c}\text { PCR } \\
\text { multiplex (TcI) } \\
\text { n/n }(\%)\end{array}$ \\
\hline \multirow{4}{*}{$\begin{array}{l}\text { Dog } \\
\text { (Canis } f \\
\text { amiliaris) }\end{array}$} & $0-1$ & 2/16 (12.5) & $0 / 16(0)$ & $1 / 16(6.2)$ & $2 / 16(12.5)$ & $1 / 16(6.2)$ & $1 / 16(6.2)$ & 4/9 (44.4) \\
\hline & $1-3$ & $9 / 20(45)$ & $1 / 20(5)$ & $0 / 20(0)$ & $4 / 20(20)$ & $4 / 20(20)$ & $0 / 20(0)$ & 3/18 (16.6) \\
\hline & $3-15$ & 9/17 (53) & $1 / 17(6)$ & 0/17 (0) & $4 / 17(23.5)$ & 2/17 (12) & 0/17 (0) & $4 / 16(25)$ \\
\hline & Total & $20 / 53(38)$ & $2 / 53(4)$ & $1 / 53(2)$ & 10/53 (19) & 7/53 (13) & $1 / 53(2)$ & $11 / 43(25.6)$ \\
\hline \multirow{4}{*}{$\begin{array}{l}\text { Cat } \\
\text { (Felis catus) }\end{array}$} & $0-1$ & $0 / 14(0)$ & 0/14 (0) & NA & $5 / 14(36)$ & NA & 2/14 (14) & $0 / 9(0)$ \\
\hline & $1-3$ & $1 / 16(6)$ & $2 / 16(12.5)$ & NA & 3/16 (19) & NA & $1 / 16(6.2)$ & $0 / 8(0)$ \\
\hline & $3-15$ & $0 / 11(0)$ & $5 / 11(45)$ & NA & $1 / 11(9)$ & NA & 2/11 (18) & $0 / 6(0)$ \\
\hline & Total & $1 / 41(2.4)$ & 7/41 (17) & NA & $9 / 41(22)$ & NA & $5 / 41(12)$ & $0 / 23(0)$ \\
\hline
\end{tabular}

Leishmania spp: Leishmania braziliensis and L. infantum; NA: does not apply.

The house construction was in good condition: $64.5 \%$ $(162 / 251)$ were constructed from masonry with plaster, $27 \%$ (68/251) masonry without plaster, 4.4\% (11/251) without clay plaster and 4\% (10/251) with clay plaster. In peridomestic environments, 437 attachments were studied and 18\% (79/437) tested positive. Among those, there was a predominance of infection in chickens at $47 \%$ (37/79); tiles, bricks and stones accounted for $24 \%$ $(19 / 79)$ and other ecotopes accounted for $16 \%$ (13/79).

In the household survey, 749 insects were captured. Of those, 369 (49.3\%) were T. brasiliensis, 377 (50.3\%) were Triatoma pseudomaculata and three $(0.04 \%)$ belonged to other species. The number of T. pseudomaculata captured in the peridomicile environments was 25 times higher than in households. Contrarily, the presence of nymphs in homes [13/15 (86.7\%)] demonstrates their ability to colonise that environment.

Wild T. brasiliensis and natural infection by T. cruzi - Among the 166 specimens of wild T. brasiliensis captured, 131 (79\%) were nymphs and 35 (21\%) were adults. Of these, a fifth stage nymph and one adult male were infected with T. cruzi.

The presence of T. brasiliensis in the wild was confirmed in the same places described for the capture of small mammals, focusing on the huge conglomerate rocks that present numerous opportunities for these and other animals to take shelter. After darkness, triatomines of all developmental stages left their hiding places and stayed on the surfaces of the stones. There was little observable movement of these insects, leading to easy capture. Interestingly, triatomine bugs present an aggressive stance, attempt to attack the captors and may even pursue them for several minutes with a distended proboscis, ready to sting (Fig. 2). The surface temperature of the rocks falls from $65^{\circ} \mathrm{C}$ in the early afternoon to approximately $30^{\circ} \mathrm{C}$ at night. Triatomines return to their hideouts approximately 21-22 h later. On some occasions, we observed adults flying, but in proportion to the number of insects visible, flying was not a routine behaviour on these occasions.

Identification of the dietary source - Cytb - The food sources of T. brasiliensis captured in their wild environments were identified from 35 DNA samples $(n=35)$. Of these, 16 ( 9 nymphs and 7 adults) confirmed the presence of the studied fragment (bandwidth $\sim 305 \mathrm{bp}$ ) corresponding to the DNA of Cytb. These samples belonged to the most anthropic environment, MPC, and to the least, CJ. The species described in Table IV as food source of insects were identified.

\section{DISCUSSION}

This study demonstrated a high serum prevalence of infection by $T$. cruzi in dogs living in the Caatinga region and this result is in agreement with other authors (Alencar 1987, Herrera et al. 2005, Xavier et al. 2007, Lima et al. 2012). Age appears to be important in determining disease prevalence because it was observed to increase with increasing age of the animals (Table II).

Dogs are considered by Gürtler et al. (1998) and Cohen and Gürtler (2001) to be an important risk factor for the transmission of T. cruzi to humans. This finding was based on the characteristics of permanent and prolonged infection and high infectivity (Gürtler et al. 1996) in triatomines compared to children or adults. The prevalence rate of $38 \%(20 / 53)$ in dogs in the study area is important in the context of T. cruzi circulation, even after progress has been made in reducing household populations by triatomine control actions. This fact was emphasised by the characterisation of TcI in dogs (Table II), showing a lineage related to the wild enzootic cycle, strengthening the close relationship between the zoonotic cycle of $T$. cruzi and the human populations in question (Xavier et al. 2007, Lima et al. 2012, Zingales et al. 2012). 
TABLE III

Abundance of wild mammals and synanthropic captured by place and time in the city of Tauá, state of Ceará, 2009 and 2010

\begin{tabular}{|c|c|c|c|c|c|c|c|c|c|}
\hline \multirow[b]{2}{*}{ Species } & \multicolumn{4}{|c|}{$\begin{array}{c}\text { Beginning of rain } \\
\text { n/n }(\%)\end{array}$} & \multicolumn{4}{|c|}{$\begin{array}{c}\text { Beginning of drought } \\
\text { n/n (\%) }\end{array}$} & \multirow[b]{2}{*}{ Abundance } \\
\hline & MPC & $\mathrm{ME}$ & $\mathrm{CJ}$ & Total & MPC & $\mathrm{ME}$ & $\mathrm{CJ}$ & Total & \\
\hline Thrichomys laurentius & $11(61)$ & $18(75)$ & $12(100)$ & $41 / 83(49.4)$ & $17(81)$ & $8(53)$ & $17(77.3)$ & $\begin{array}{l}42 / 83 \\
(50.6)\end{array}$ & $83(74)$ \\
\hline Kerodon rupestris & $3(17)$ & $2(8.3)$ & - & $5 / 11(45.4)$ & $4(19)$ & - & $2(9.1)$ & $\begin{array}{c}6 / 11 \\
(54.5)\end{array}$ & $11(10)$ \\
\hline Rattus rattus ${ }^{a}$ & - & $2(8.3)$ & - & $2 / 5(40)$ & - & $3(20)$ & - & $3 / 5(60)$ & $5(4.5)$ \\
\hline Didelphis albiventris & - & $1(4.2)$ & - & $1 / 4(25)$ & - & $3(20)$ & - & $3 / 4(75)$ & $4(3.5)$ \\
\hline Monodelphis domestica & $1(5.5)$ & - & - & $1 / 3(33.3)$ & - & $1(7)$ & $1(4.5)$ & $\begin{array}{c}2 / 3 \\
(66.7)\end{array}$ & $3(2.6)$ \\
\hline Galea spixii & $2(11)$ & - & - & $2 / 2(100)$ & - & - & - & $0 / 2(0)$ & $2(1.8)$ \\
\hline Wiedomys pyrrhorinos & - & - & - & $0 / 2(0)$ & - & - & $2(9.1)$ & $2 / 2(100)$ & $2(1.8)$ \\
\hline Conepatus semistriatus & $1(5.5)$ & - & - & $1 / 1(100)$ & - & - & - & $0 / 1(0)$ & $1(0.9)$ \\
\hline Mus musculus ${ }^{b}$ & - & $1(4.2)$ & - & $1 / 1(100)$ & - & - & - & $0 / 1(0)$ & $1(0.9)$ \\
\hline Total & $\begin{array}{l}18 / 54 \\
(33.3)\end{array}$ & $\begin{array}{l}24 / 54 \\
(44.4)\end{array}$ & $\begin{array}{l}12 / 54 \\
(22.3)\end{array}$ & $\begin{array}{c}54 / 112 \\
(48.2)\end{array}$ & $\begin{array}{l}21 / 58 \\
(36.2)\end{array}$ & $\begin{array}{l}15 / 58 \\
(25.8)\end{array}$ & $\begin{array}{c}22 / 58 \\
(38)\end{array}$ & $\begin{array}{l}58 / 112 \\
(51.8)\end{array}$ & $\begin{array}{c}112 \\
(100)\end{array}$ \\
\hline
\end{tabular}

$a$ : intradomiciliary capture at the request of a resident; $b$ : captured in nest of casaca-de-couro (Pseudoseisura cristata); CJ: Cachoeira do Júlio; ME: Seu Evangelista; MPC: Pedra da Cruz.

The occurrence of mixed infection with L. infantum $[13 \%(7 / 53)]$ and Leishmania spp [19\% (10/53)] in dogs was expected because visceral leishmaniasis is endemic in the municipality of Tauá.

In cats, we obtained results that support the occurrence of mixed infections, where 22\% (9/41) of samples reacted to T. cruzi and Leishmania spp, peaking at $36 \%$ $(5 / 14)$ in smaller animals more than a year old. Among those animals surveyed, four were six-nine months old and two were found living in the same house with three dogs over five years old that had positive serology for $T$. cruzi and/or L. infantum.

Comparing our results for dogs and cats, we find that $38 \%(20 / 53)$ of dogs had positive serology for $T$. cruzi, while only $2.4 \%(1 / 41)$ of cats did, with significant differences in their age distributions (Table II). Dogs have been described as frequent sources of blood for triatomines, sometimes even more so than humans (Gürtler et al. 1996), chickens or cats (Gürtler et al. 2009).

The management of domestic animals should be taken into account when defining the risk area for the transmission of T. cruzi. According to their displacement or confinement, it is possible to determine these animals' degree of exposure to the transmission cycle and their proximity to homes (Roque \& Jansen 2008). The use of pets as sentinels in the identification of risk areas for the transmission of $T$. cruzi has been proposed in countries such as the United States of America, Venezuela, Mexico and Argentina (Shadomy et al. 2004, Crisante et al. 2006, Estrada-Franco et al. 2006, Gürtler et al. 2007). As such, depicting the profile of infection in these ani- mals allows the real and imminent risk of transmission to humans to be determined.

Goats and sheep accounted for 58.3\% (185/317) of our samples and we obtained an infection prevalence of only $1 \%(1 / 102)$ among sheep. This prevalence proved to be extremely low compared to other studies (Marzochi et al. 1987, Rozas et al. 2005), confirming only the results obtained by Herrera et al. (2005), who identified a $2 \%(1 / 56)$ prevalence rate in samples from caprines in the state of Piauí. Perhaps the choice of animals up to six months of life explains the low prevalence rate found in our study.

These animals remain loose to eat and drink during the day and are collected in corrals in the evening. These corrals surround the homes, are constructed of native wood and generally contain stony places where the presence of $T$. brasiliensis is easily verified.

Thus, although we have not identified an important prevalence in sheep in accordance with other studies, the link between sheep, goats and triatomines is an intimate and persistent one, not only in the wild environment, but also around homes, where these animals represent a significant food source for these insects and are thus vulnerable to the transmission cycle of $T$. cruzi.

The sample of pigs represented $10.6 \%$ (34/317) of our study, with a prevalence rate of $6 \%(2 / 34)$ and suspected infection rate of $26.5 \%(9 / 34)$. These animals are common in the study area, but the collection of blood samples was limited due to the difficulty of capturing the animals. The vast majority of pigs live in small herds and while they frequent peridomicile areas for feeding and sleeping, they do not allow humans to approach with 


\section{TABLE IV}

Dietary sources of wild Triatoma brasiliensis, identified by cytochrome b in the city of Tauá, state of Ceará, 2009

\begin{tabular}{lc}
\hline Dietary source & $\mathrm{n}(\%)$ \\
\hline Galea spixii & $5(31.3)$ \\
Kerodon rupestris & $4(25)$ \\
Capra hircus & $3(18.8)$ \\
Tropidurus oreadicus & $2(12.5)$ \\
Tupinambis merianae & $1(6.2)$ \\
Gallus gallus & $1(6.2)$ \\
\hline Total & $16(100)$ \\
\hline
\end{tabular}

ease. Confounding other limitations, such as the difficulty of access to the animals that exist in peridomicile environments, goats and sheep are released during the day, which makes it difficult to collect blood samples.

Pigs were recently included on the list of peridomestic animals that may be important in the transmission cycle of $T$. cruzi, especially in prevalence areas of acute Chagas disease (Roque \& Jansen 2008, Roque et al. 2008), where high prevalence are described, but with a low incidence of parasitosis.

T. laurentius, caviomorph rodents that are mainly associated with rocky sites in semiarid regions, were the most abundant species at all sites studied by us, which is in agreement with Herrera et al. (2005), Xavier et al. (2007) and Roque et al. (2008). The greatest species diversity was in $\mathrm{ME}$, considered by us to be susceptible to human interference at an intermediate level. We note that the capture of $R$. rattus occurred in households and that of M. musculus in a nest of casaca-de-couro (Pseudoseisura cristata). The capture of D. albiventris occurred only in places where we also expected greater human modifications to the environment. The ability of these animals to adapt to this environment is recognised and cited as one of the factors that make them an important reservoir of $T$. cruzi.

Contrary to what is found in the literature, we found that the areas in the locality of $\mathrm{CJ}$ that had the lowest richness of mammals were the most isolated areas and distant from human action. Most studies of small mammals have shown that greater human action corresponds to the greater simplification of fauna, with a predominance of synanthropic animals such as marsupials and rodents that can roam between the human and wild environments (Mills \& Childs 1998, Roque et al. 2008). There was a huge difference in the capture success between the four campaigns, even with an increase in the capture effort. It is known that the density of small mammals is mainly related to the availability of water. According to data from the National Institute of Meteorology, the amount of precipitation for Tauá was regularly above average between 2007-2009, indicating that water was available in the environments inhabited by these animals, even during droughts. This fact is reflected in the ease of capture of these populations in 2009, when males, females, adults and juveniles were sampled. In 2010 , there was a significant decrease in precipitation and, consequently, an abrupt decrease in the animal populations sampled, with a predominance of young males. Although T. laurentius has been described as important in the transmission cycle and/or maintenance of T. cruzi in the semiarid region (Herrera et al. 2005, Xavier et al. 2007, Roque et al. 2008), none of our samples amplified fragments that characterised the presence of $T$. cruzi DNA, confirming the negative cytological examination. These data show that these animals, although the most abundant, do not participate in the amplification cycle of T. cruzi in the sampled area.

Only $6.2 \%$ (7/112) of wild animals captured were marsupials ( $4 \mathrm{D}$. albiventris and $3 \mathrm{M}$. domestica) and none were infected by $T$. cruzi. The fact that we captured $71 \%(5 / 7)$ of these animals, mostly adults, at the beginning of the dry season suggests dispersion or further exploration of the environment because the traps were placed at ground level.

Locations with greater diversity of environments provide greater opportunities to be exploited by hosts of $T$. cruzi. These habitats are occupied by different species of mammals with different degrees of susceptibility that exert different pressures on the parasite and, consequently, shape an epidemiological scenario of greater diversity for T. cruzi (Rozas et al. 2007, Xavier et al. 2007, Jansen \& Roque 2010). Thus, even without the detection of parasitosis by direct examination and multiplex PCR, the capture
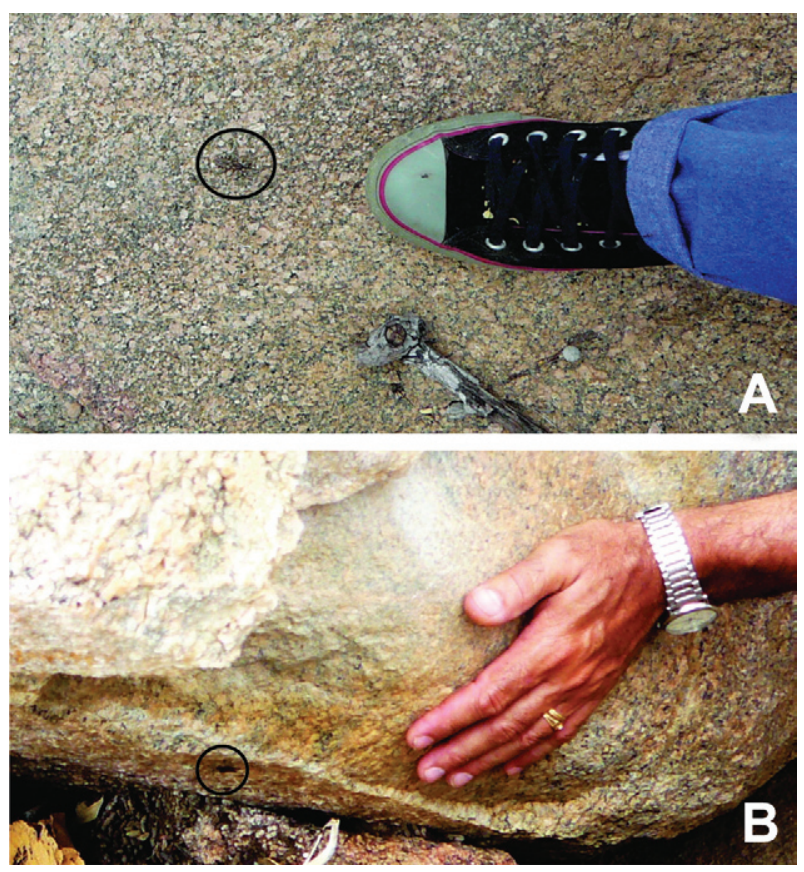

Fig. 2: attack of adult (A) and nymph (B) of Triatoma brasiliensis (with extended proboscis) in the wild environment during the day. Source: L Diotaiuti (October/2010). 
of rodents and marsupials that are recognisably important in maintaining and/or amplifying the $T$. cruzi cycle in environments that have been known to be infested by $T$. brasiliensis leads us to reflect on the animals' exposure to the parasite. Regarding the degree of human interference in these locations, it will be possible to define areas of interface between domestic and wild environments that pose a risk in the transmission of T. cruzi.

T. pseudomaculata, predominantly a peridomestic species, was found to colonise the interior of homes successfully through the predominance of nymphs in that environment (87\%). This ability rests primarily on $\mathrm{T}$. brasiliensis, capable of colonising $12.3 \%$ of the intradomiciliary environments investigated, even with over than $60 \%$ of homes investigated having good construction conditions.

In the peridomicile environment, some ecotopes have been more attractive for the development of the insects (Cecere et al. 2004). In our study, chickens were the most infested ecotopes, followed by tiles, bricks and stones, agreeing in part with Sarquis et al. (2006), who found greater infestations in goat sties and chicken perches. Diotaiuti et al. (2000) demonstrated that perches (33\%), chickens (24\%) and goat and sheep pens (14\%) are the most important ecotopes. This result shows the similarities and particularities of the epidemiological profile of each region and the influences of environmental, socioeconomic and cultural factors. Interventions to prevent human disease will be more effective if these differences are known and taken into consideration.

The prevalence of nymphs of $T$. brasiliensis in all environments shows the importance of this species as a vector of T. cruzi. No other species captured were parasitised and T. brasiliensis was positive for T. cruzi in the three investigated environments, including indoors, posing a real risk of transmission of the parasite. In a study performed in CE, Lorenzo et al. (2000) showed that microclimatic similarities between wild habitats (rocks) and hiding places in indoor walls favour the adaptation of $T$. brasiliensis to the artificial environment. Thus, indoor locales are an attractive environment for T. brasiliensis because they provide appropriate environmental conditions, such as availability of stable food sources throughout the year (Diotaiuti 2007).

The complexity of the peridomicile environment is such that the impact of the renewal of attachments between one spraying and another, as well as the preference of insects per type of renovated attachment, directly affects the rate of colonisation (Oliveira-Lima et al. 2000). Moreover, the action of pyrethroid insecticides is limited because they do not reach all hiding locations and the pesticide's residual action is reduced by bright light, high temperatures, wind and rain, further facilitating the process of colonisation of the insects in the Northeast Region (Diotaiuti et al. 2000, Oliveira Filho et al. 2000). This condition is further amplified as a result of contiguity between natural and artificial ecotopes, overlapping habitats and facilitating interaction between triatomines and humans, increasing the risk of transmission of T. cruzi (Borges et al. 2005, Moncayo \& Silveira 2009, Sarquis et al. 2012). According to Gürtler et al. (2005), the failure to conduct entomological surveillance in areas infested by T. infestans in Argentina, including the lack of comprehensive and regular insecticide coverage and a lack of supervision, have led to a rapid recovery of the insect population after two-three years and to a restoration of household transmission.

The ease with which $T$. brasiliensis invades and colonises a wide variety of peridomiciliary structures allows the animals and, therefore, the infection to transit between these environments, connecting the cycle of T. cruzi with households. In our study, the peridomicile environment was the locale in which insects had the highest natural infection at $14 \%(22 / 157)$, even though chicken areas were the most infested ecotopes. This fact emphasises the need to identify the ecological and biological aspects of the relationship of triatomines with the different sources of peridomestic infection to implement entomological surveillance due to the importance of houses in the re-colonisation of habitats (Abad-Franch et al. 2005, Noireau et al. 2005, Guhl et al. 2009).

Complementing the list of animals associated with $T$. brasiliensis in wild environments, the blood ingested by triatomine was identified using molecular techniques. Among the food sources identified, 56\% (9/16) belonged to rodents that live in the same environment, while $18.7 \%$ (3/16) were goats associated with rock formations and raised in a semi-extensive way. The association with reptiles and birds $(25 \%, 4 / 16)$ may have limited natural infection of triatomines in sylvatic cases, as we recorded (Table IV).

Another behaviour that demonstrates the ecological valence and opportunistic character of $T$. brasiliensis is their aggressiveness in seeking a blood meal after leaving their shelters. Fig. 2 illustrates one of these attacks that we witnessed, where the insect was able to pursue its prey for food, sometimes even during the day.

In the Caatinga region, life and agricultural production are highly dependent on plant resources. The natives from the region draw numerous products and services from the land to make life possible in the semiarid area. The use of soil, terrain, flora and fauna by humans means that there is a close relationship between human life and diverse organisms. The secular process of occupation of the area has contributed to the general deterioration of its vegetation, resulting in a profound modification of the primary vegetation cover (Meunier \& Ferraz 2005). Only with the development of strategies for regional conservation through the sustainable use of natural resources in the region and by seeking to preserve the diversity and stop the increase in desertification will it be possible to maintain ecological services required for rural populations and their livelihoods (Leal et al. 2005).

Preserving ecosystems and maintaining their diversity should generally reduce the prevalence of infectious diseases (Keesing et al. 2006, 2010). The increase in species diversity may reduce the risk of infection because it reduces the chances of the animal population becoming simplified through the selection of one or more species that have the ability to maintain or amplify a parasite and favour transmission (Ostfeld \& Keessing 2000, Pinto et al. 2006).

A reflection on human behaviour as the primary responsible factor affecting environmental change on our planet and all of the consequences that this act represents 
fit in this context. Governments and societies have key roles in building solutions so that sustainable development is strengthened as a paradigm for all relevant actors in the economic, social and environmental areas. Only by reaching a consensus on the complementarity of these three pillars of development can we accomplish the sustainability needed and ensure the supply of current human needs without compromising the future of the next generation.

As in all biomes, survival in semiarid regions is closely related to the use of natural resources and to the development of regional conservation strategies. Only then is it possible to maintain ecological services as required by rural populations and their livelihoods. Preserving ecosystems, maintaining their diversity, increasing the stagnation of desertification and appreciating different ways of life will contribute to increasing the possibilities for answers that allow for a balance between health, environment and sustainable development.

The high prevalence of infection by $T$. cruzi observed in domestic and outdoor animals strengthens the close relationship between the enzootic cycle and human populations. The creation of peridomestic animal environments close to human habitations is important to ensure the safety of these "goods" and is a characteristic of life in semi-arid northeast regions. Chagas disease in the Northeast Region has peculiar characteristics when compared to the vast endemic areas that have $T$. infestans as their main species. The status represented by this species as the most important vector in the transmission of Chagas disease has failed to take into account native species, diminishing their importance. This perspective is indeed erroneous because, in the locale where indigenous species are prevalent and where T. infestans is present, these species are responsible for the domestic transmission of the disease. Adding to this consideration is the difficulty of controlling these species because they are in their natural environment and exert relentless pressure to colonise free environments. In this context, the presence of the parasite around homes is a valid risk factor for the transmission of Chagas disease in this region and this transmission may be aggravated if control measures are flawed, interrupted or discontinued.

\section{ACKNOWLEDGEMENTS}

To the municipality of Tauá, the 14th Regional Health Tauá, especially Dulce Maria Feitosa (coordinator) and José Silvério do Nascimento Júnior, to Estevão Curado and Asevedo Quirino de Sousa, for their unconditional support, and to the PDTIS-Fiocruz, for the use of its facilities.

\section{REFERENCES}

Abad-Franch F, Palomeque FS, Aguilar HM, Miles MA 2005. Field ecology of sylvatic Rhodnius populations (Heteroptera, Triatominae): risk factors for palm tree infestation in western Ecuador. Trop Med Int Health 10: 1258-1266.

Alencar JE 1987. História natural da doença de Chagas no estado do Ceará, Imprensa Universitária da UFC, Fortaleza, 341 pp.

Araújo A, Jansen AM, Reinhard K, Ferreira LF 2009. Paleoparasitology of Chagas disease - A review. Mem Inst Oswaldo Cruz 104 (Suppl. I): 9-16.

Ashford RW 1996. Leishmaniasis reservoirs and their significance in control. Clin Dermatol 14: 523-532.
Ashford RW 1997. What it takes to be a reservoir host. Belg J Zool 127: 85-90.

Borges EC, Dujardin JP, Schofield CJ, Romanha AJ, Diotaiuti L 2005. Dynamic between sylvatic, peridomestic and domestic populations of Triatoma brasiliensis (Hemiptera: Reduviidae) at the municipality of Independência, northeastern Brazil. Acta Trop 93: 119-126.

Camargo ME 1966. Fluorescent antibody test for the serodiagnosis of American trypanosomiasis. Technical modification employing preserved culture forms of Trypanosoma cruzi in a slide test. Rev Inst Med Trop Sao Paulo 8: 227-235.

Carbajal-de-la-Fuente AL, Minoli SA, Lopes CM, Noireau F, Lazzari CR, Lorenzo MG 2007. Flight dispersal of the Chagas disease vectors Triatoma brasiliensis and Triatoma pseudomaculata in northeastern Brazil. Acta Trop 101: 115-119.

Ceballos LA, Cardinal MV, Vazquez-Prokopec GM, Lauricella MA, Orozco MM, Cortinas R, Schijman AG, Levin MJ, Kitron U, Gürtler RE 2006. Long-term reduction of Trypanosoma cruzi infection in sylvatic mammals following deflorestation and sustained vector surveillance in northwestern Argentina. Acta Trop 98: 286-296.

Cecere MC, Vasquez-Prokopec GM, Gürtler RE, Kitron U 2004. Spatio-temporal analysis of reinfestation by Triatoma infestans (Hemiptera: Reduviidae) following insecticide spraying in a rural community in northwestern Argentina. Am J Med 71: 803-810.

Cohen JE, Gürtler RE 2001. Modeling household transmission of American trypanosomiasis. Science 293: 694-698.

Crisante G, Rojas A, Teixeira MM, Anez N 2006. Infected dogs as a risk factor in the transmission of human Trypanosoma cruzi infection in western Venezuela. Acta Trop 98: 247-254.

D'Andrea OS, Jansen AM, Bezerra CM, Roque ALR, Teixeira BR, Lima VS 2006. Relatório de atividades: avaliação do ciclo de transmissão silvestre do Trypanosoma cruzi na área de ocorrência do surto de doença de Chagas em Redenção/CE - Levantamento faunistico e diagnóstico da infecção, Rio de Janeiro, 125 pp.

Dias JCP 2000. Vigilância epidemiológica em doença de Chagas. Cad Saude Publica 16 (Suppl. 2): 43-59.

Dias JCP, Machado EMM, Fernandes AL, Vinhaes MC 2000. Esboço geral e perspectivas da doença de Chagas no nordeste do Brasil. Cad Saude Publica 16 (Suppl. 2): 13-34.

Diotaiuti L 2007. Triatomíneos. In A Teixeira, Doença de Chagas e evolução, Editora Universitária de Brasília, Brasília, p. 205-231.

Diotaiuti L, Faria Filho OF, Carneiro FCF, Dias JCP, Pires HHR, Schofield CJ 2000. Aspectos operacionais do controle do Triatoma brasiliensis. Cad Saude Publica 16 (Suppl. 2): 61-67.

Estrada-Franco JG, Bhatia V, Az-Albiter H, Ochoa-Garcia L, Barbabosa A, Vazquez-Chagoyan JC, Martinez-Perez MA, GuzmanBracho C, Garg N 2006. Human Trypanosoma cruzi infection and seropositivity in dogs, Mexico. Emerg Infect Dis 12: 624-630.

FIOCRUZ - Fundação Oswaldo Cruz 2008. Curso de capacitação dos microscopistas de malária e dos laboratoristas da rede pública para detecção do Trypanosoma cruzi, Módulo II, Fiocruz, Rio de Janeiro, 208 pp.

Forattini OP 1980. Biogeografia, origem e distribuição da domiciliação de triatomíneos no Brasil. Rev Saude Publica 14: 265-299.

Guhl F, Pinto N, Aguilera G 2009. Sylvatic triatominae: a new challenge in vector control transmission. Mem Inst Oswaldo Cruz 104 (Suppl. I): 71-75.

Gurgel-Gonçalves R, Galvão C, Costa J, Peterson A 2012. Geographic distribution of Chagas disease vectors in Brazil based on ecological niche modeling. J Trop Med 2012: 1-15.

Gürtler RE, Ceballos LA, Ordóñez-Krasnowski P, Lanati LA, Stariolo R, Kitron U 2009. Strong host-feeding preferences of the vector Triatoma infestans modified by vector density: implications for the epidemiology of Chagas disease. PLoS Negl Trop Dis 3: 1-12. 
Gürtler RE, Cecere MC, Castañera MB, Canale DN, Lauricella MA, Chuit R, Cohen JE, Segura EL 1996. Probability of infection with Trypanosoma cruzi of the vector Triatoma infestans fed on infected humans and dogs in northwest Argentina. Am J Med 55: 24-31.

Gürtler RE, Cecere MC, Lauricella MA, Cardinal, MV, Kitron U, Cohen JE 2007. Domestic dogs and cats as sources of Trypanosoma cruzi infection in rural northwestern Argentina. Parasitology 134: 69-82.

Gürtler RE, Cecere MC, Lauricella MA, Petersen RM, Chuit R, Segura EL, Cohen JE 2005. Incidence of Trypanosoma cruzi infection among children following domestic reinfestation after insecticide spraying in rural northwestern Argentina. Am J Med 73: 95-103.

Gürtler RE, Cohen JE, Cecere MC, Chuit R, Segura EL 1998. Influence of humans and domestic animals on the household prevalence of Trypanosoma cruzi in Triatoma infestans populations in northwest Argentina. Am J Med 58: 748-758

Herrera L, D‘Andrea PS, Xavier SCC, Mangia RH, Fernandes O, Jansen AM 2005. Trypanosoma cruzi infection in wild mammals of the National Park 'Serra da Capivara' and its surroundings (Piauí, Brazil), an area endemic for Chagas disease. Trans $R$ Soc Trop Med Hyg 99: 379-388.

IPECE - Instituto de Pesquisa e Estatística Econômica do Ceará 2012. Perfil básico municipal de Tauá 2012. Available from: ipece. ce.gov.br/publicacoes/perfil_basico/pbm-2012/Taua.pdf.

Jansen AM 2009. Ecologia. Available from: fiocruz.br/chagas/cgi/ cgilua.exe/sys/start.htm?sid=141.

Jansen AM, Roque ALR 2010. Domestic and wild mammalian reservoirs. In J Telleria, M Tibayrenc, American trypanosomiasis, Chagas disease: one hundred years of research, Elsevier, Burlington, p. 249-276.

Keesing F, Belden LK, Daszak P, Dobson A, Harvell CD, Holt RD, Hudson P, Jolles A, Jones KE, Mitchell CE, Myers SS, Bogich T, Ostfeld RS 2010. Impacts of biodiversity on the emergence and transmission of infectious diseases. Nature 468: 647-652.

Keesing F, Holt RD, Ostfeld RS 2006. Effects of species diversity on disease risk. Ecol Lett 9: 485-498.

Kocher TD, Thomas WK, Meyer A, Edwards SV, Paabo S, Villablanca FX, Wilson AC 1989. Dynamics of mitochondrial DNA evolution in animals: Amplification and sequencing with conserved primers (cytochrome b/12S ribosomal DNA/control region/evolutionary genetics/molecular phylogenies). Proc Natl Acad Sci USA 86: 6196-6200.

Leal IR, da Silva JMC, Tabarelli M, Lacher TE 2005. Changing the course of biodiversity conservation in the Caatinga of northeastern Brazil. Conserv Biol 19: 701-706.

Lent H, Wygodzinsky P 1979. Revision of the Triatominae (Hemiptera, Reduviidae) and their significance as vectors of Chagas' disease. Bull Am Mus Nat Hist 163: 123-520.

Lima MM, Sarquis O, de Oliveira TG, Gomes TF, Coutinho C, Daflon-Teixeira NF, Toma HK, Britto C, Teixeira BR, D’Andrea PS, Jansen AM, Bóia MN, Carvalho-Costa FA 2012. Investigation of Chagas disease in four periurban areas in northeastern Brazil: epidemiologic survey in man, vectors, non-human hosts and reservoirs. Trans R Soc Trop Med Hyg 106: 143-149.

Lorenzo MG, Guarneri AA, Pires HH, Diotaiuti L, Lazzari CR 2000. Microclimatic properties of the Triatoma brasiliensis habitat. Cad Saude Publica 16 (Suppl. 2): 69-74.

Machado EMM, Alvarenga NJ, Romanha AJ, Grisard EC 2000. A simplified method for sample collection and DNA isolation for polymerase chain reaction detection of Trypanosoma rangeli and Trypanosoma cruzi in triatomine vectors. Mem Inst Oswaldo Cruz 95: 863-866

Marzochi MCA, Fuentes AR, Meneses AP 1987. Primeira evidência da infecção natural caprina Trypanosoma cruzi associado ao Triatoma brasiliensis no Brasil. Rev Soc Bras Med Trop 20 (Suppl.): 89-90.
Meunier I, Ferraz J 2005. As Caatingas. Available from: nordesterural.com.br/dev/nordesterural/matler.asp? newsId=2359.

Mills JN, Childs JE 1998. Ecologic studies of rodent reservoirs: their relevance of human health. Emerg Infect Dis 4: 529-537.

Moncayo A, Silveira AC 2009. Current epidemiological trends for Chagas disease in Latin America and future challenges in epidemiology, surveillance and health policy. Mem Inst Oswaldo Cruz 104 (Suppl. I): 17-30.

Moreira D, Lopez-Garcia P, Vickerman P 2002. An updated view of kinetoplastid phylogeny using environmental sequences and a closer outgroup: proposal for a new classification of the class Kinetoplastea. Int J Syst Evol Microbiol 54: 1861-1875.

MS/SUCAM - Ministério da Saúde/Superintendência de Campanhas de Saúde Pública 1980. Manual de normas técnicas da campanha de controle da doença de Chagas, MS/SUCAM, Brasília, 167 pp.

MS/SVS - Ministério da Saúde/Secretaria de Vigilância em Saúde 2006. Manual de vigilância e controle da leishmaniose visceral, 2nd ed., MS/SVS, Brasília, 122 pp.

MS/SVS - Ministério da Saúde/Secretaria de Vigilância em Saúde 2011. Nota técnica conjunta $n^{\circ} 01 / 2011$, CGDT-CGLAB/DEVIT/ SVS-MS, Brasília, 3 pp.

Noireau F, Carbajal-de-la-Fuente AL, Lopes CM, Diotaiuti L 2005. Some considerations about the ecology of Triatominae. An Acad Bras Cienc 77: 431-436.

Noireau F, Diosque P, Jansen AM 2009. Trypanosoma cruzi: adaptation to its vectors and its hosts. Vet Res 40: 26.

Oliveira Filho AM, Melo MTV, Santos CE, Faria Filho OF, Carneiro FCF, Oliveira-Lima JW, Vieira JBF, Gadelha FV, Ishihata J 2000. Tratamentos focais e totais com inseticidas de ação residual para o controle de Triatoma brasiliensis e Triatoma pseudomaculata no nordeste brasileiro. Cad Saude Publica 16 (Suppl. 2): 105-111.

Oliveira VPV 2006. A problemática da degradação dos recursos naturais no domínio dos sertões secos do estado do Ceará-Brasil. In JB Silva, EWC Dantas, ME Zanella, AJA Meireles (orgs.), Litoral e sertão - natureza e sociedade no nordeste brasileiro, Expressão Gráfica, Fortaleza, p. 187-199.

Oliveira-Lima JW, Faria Filho OF, Vieira JBF, Gadelha FV, Oliveira Filho AM 2000. Alterações do peridomicílio e suas implicações para o controle do Triatoma brasiliensis. Cad Saude Publica 16 (Suppl. 2): 75-81.

OPAS - Organização Panamericana de Saúde 2006. Enfermedad de Chagas (tripanosomiasis americana). Available from: paho.org/ spanish/ad/dpc/cd/chagas.htm.

Ostfeld RS, Keesing F 2000. Biodiversity and disease risk: the case of Lyme disease. Conserv Biol 14: 722-728.

Pinto CM, Ocaña-Mayorga S, Lascano MS, Grijalva MJ 2006. Infection by trypanosomes in marsupials and rodents associated with human dwellings in Ecuador. Int J Parasitol 92: 1251-1255.

Roque ALR, Jansen AM 2008. Importância dos animais domésticos sentinelas na identificação de áreas de risco de emergência de doença de Chagas. Rev Soc Bras Med Trop 4 (Suppl. 3): 191-193.

Roque ALR, Xavier SCC, da Rocha MG, Duarte AC, D'Andrea PS, Jansen AM 2008. Trypanosoma cruzi transmission cycle among wild and domestic mammals in three areas of orally transmitted Chagas disease outbreaks. Am J Med 79: 742-749.

Rozas M, Botto-Mahan C, Coronado X, Ortiz S, Cattan PE, Solari A 2005. Short report: Trypanosoma cruzi infection in wild mammals from a chagasic area of Chile. Am J Med 73: 517-519.

Rozas M, Botto-Mahan C, Coronado X, Ortiz S, Cattan PE, Solari A 2007. Coexistence of Trypanosoma cruzi genotypes in wild and peridomestic mammals in Chile. Am J Med 77: 647-653. 
Sarquis O, Carvalho-Costa FA, Toma HK, Georg I, Burgoa MR, Lima MM 2012. Eco-epidemiology of Chagas disease in northeastern Brazil: Triatoma brasiliensis, T. pseudomaculata and Rhodnius nasutus in the sylvatic, peridomestic and domestic enviroments. Parasitol Res 110: 1481-1485.

Sarquis O, Sposina R, de Oliveira TG, Mac Cord JR, Cabello PH, Borges-Pereira J, Lima MM 2006. Aspects of peridomiciliary ecotopes in rural areas of northeastern Brazil associated to triatomine (Hemiptera, Reduviidae) infestation, vectors of Chagas disease. Mem Inst Oswaldo Cruz 101: 143-147.

Shadomy SV, Waring SC, Martins-Filho OA, Oliveira RC, Chappell CL 2004. Combined use of enzyme-linked immunosorbent assay and flow cytometry to detect antibodies to Trypanosoma cruzi in domestic canines in Texas. Clin Diagn Lab Immunol 11: 313-319.

Silveira AC, Feitosa VR, Borges R 1984. Distribuição de triatomíneos domiciliados no período 1975/1983 no Brasil. Rev Bras Malariol D Trop 36: 15-312.
Silveira AC, Rezende DF 1994. Epidemiologia e controle da transmissão vetorial da doença de Chagas no Brasil. Rev Soc Bras Med Trop 27: 5-16.

Torres TZG, Magnanini MMF, Luiz RR 2008. Amostragem. In R Medronho, KV Bloch, RR Luiz, GL Werneck (orgs.), Epidemiologia, 2nd ed., Atheneu, São Paulo, p. 403-414.

Truett GE, Heeger P, Mynatt RL, Truett AA, Walker JA, Warman ML 2000. Preparation of PCR-quality mouse genomic DNA with hot sodium hydroxide and tris (HotSHOT). Biotechniques 29: 52-54.

Xavier SCC, Vaz VC, D'Andrea PS, Herrera L, Emperaire L, Alves JR, Fernandes O, Ferreira LF, Jansen AM 2007. Mapping of the distribution of Trypanosoma cruzi infection among small wild mammals in a conservation unit and its surroundings (NortheastBrazil). Parasitol Int 56: 119-128.

Zingales B, Miles MA, Campbell DA, Tibayrenc M, Macedo AM, Teixeira MMG, Schijman AG, Llewellyn MS, Lages-Silva E, Machado CR, Andrade SG, Nancy R, Sturm NR 2012. The revised Trypanosoma cruzi subspecific nomenclature: rationale, epidemiological relevance and research applications. Infect Genet Evol 12: 240-253. 